\title{
INFERENCES ABOUT MAGMA SOURCES AND MANTLE STRUCTURE FROM VARIATIONS OF ${ }^{143} \mathrm{Nd} /{ }^{144} \mathrm{Nd}$
}

\author{
D. J. DePaolo and G. J. Wasserburg \\ The Lunatic Asylum of the Charles Arms Laboratory, Division of Geological and Planetary Sciences*, \\ California Institute of Technology, Pasadena, California 91125
}

\begin{abstract}
Continental flood basalts and mid-ocean ridge (MOR) tholeiitic basalts have distinctly different ${ }^{143} \mathrm{Nd} /{ }^{144} \mathrm{Nd}$ which may permit a priori distinction between "continental" and "oceanic" igneous rocks. Initial ${ }^{143} \mathrm{Nd} /{ }^{144} \mathrm{Nd}$ of continental igneous rocks through time fall on a $\mathrm{Sm} / \mathrm{Nd}$ evolution curve with chondritic REE abundance ratio. These observations indicate that many continental igneous rocks are derived from a reservoir with chondritic REE pattern which may represent primary material remanning since the formation of the earth. Oceanic igneous rocks are derived from a different ancient reservoir which has $\mathrm{Sm} / \mathrm{Nd}$ higher than chondritic. Initial ${ }^{143} \mathrm{Nd} /{ }^{144} \mathrm{Nd}$ and ${ }^{87} \mathrm{Sr} /{ }^{86} \mathrm{Sr}$ in young basalts from both oceans and continents show a strong correlation suggesting that $\mathrm{Sm}-\mathrm{Nd}$ and $\mathrm{Rb}-\mathrm{Sr}$ fractionation events in the mantle may be correlative and caused by the same process. From this correlation $\mathrm{Rb} / \mathrm{Sr}$ for the earth is inferred to be 0.029 .
\end{abstract}

This study was undertaken to determine if there exists a systematic difference in ${ }^{143} \mathrm{Nd} /{ }^{144} \mathrm{Nd}$ between young volcanic rocks from ocean basins and continental areas. It builds upon a small body of Nd isotopic data which suggested this contrast (DePaolo and Wasserburg, 1976, referred to as DPW). In the same study it was shown that continental igneous rocks of varying ages appear to be derived from a single uniform reservoir with chondritic relative REE abundances. Typical old continental crustal material was found to have ${ }^{143} \mathrm{Nd} /{ }^{144} \mathrm{Nd}$ today which is drastically different from that of young basalts suggesting that ${ }^{143} \mathrm{Nd} /{ }^{144} \mathrm{Nd}$ could be used to identify products of remelted ancient crust. This study tests with an extended data base the hypotheses that continental igneous rocks through time have been derived from a uniform reservoir with chondritic $\mathrm{Sm} / \mathrm{Nd}$ (CHUR) and that oceanic igneous rocks are derived from a distinctly different reservoir. In addition it presents evidence that variations in initial ${ }^{143} \mathrm{Nd} /{ }^{144} \mathrm{Nd}$ and ${ }^{87} \mathrm{Sr} /{ }^{86} \mathrm{Sr}$ in young volcanic rocks are correlated.

To test these hypotheses ${ }^{143} \mathrm{Nd} /{ }^{144} \mathrm{Nd},{ }^{87} \mathrm{Sr} /{ }^{86} \mathrm{Sr}, \mathrm{Sm} / \mathrm{Nd}$ and $\mathrm{Rb} / \mathrm{Sr}$ were measured in three groups of samples. 1) Mid-ocean ridge (MOR) tholeiitic basalts and continental flood basalts were measured to compare oceanic and continental magmas, since these represent the most voluminous lava types found in the two settings; 2) Samples of various volcanic lithologies from continents, including alkali basalt, rhyolite, and a carbonatite and basalts from oceanic islands were measured to further explore the variations found in young volcanic rocks; 3) Initial ${ }^{143} \mathrm{Nd} /{ }^{144} \mathrm{Nd}$ in five more Precambrian continental intrusive rocks of various ages were determined to further evaluate the uniform reservoir hypothesis for continental igneous rocks.

Analytical Procedure and Data: Chemical separation of Sm and Nd and mass spectrometry have been described by Eugster et al. (1970) and $D P W$. For all samples measured in this study, no corrections to $\mathrm{Nd}$ isotope ratios were necessary due to interferences from other species in the ion spectra or from chemistry blank. The intensity of the ${ }^{144} \mathrm{NdO}$ ion beam was between 3 and $6 \times 10^{-11} \mathrm{~A}$ during data acquisition. All Nd isotopes were measured in every run. The measured values for the non-radiogenic Nd isotopes for all runs are shown in Figure 1. Strontium was separated using conventional ion exchange techniques. ${ }^{87} \mathrm{Sr} /{ }^{86} \mathrm{Sr}$ are normalized to ${ }^{86} \mathrm{Sr} /{ }^{88} \mathrm{Sr}=0.1194$.

*Division Contribution No. 2830

Copyright 1976 by the American Geophysical Union.
Isotopic data, locations, and lithologic classifications for all samples are given in Table 1 and summarized in Figures 2, 3, and 4. Nd data are expressed using the notation of $D P W$.

Results. I. Continental Flood Basalt and MOR Tholeites: $\mathrm{Nd}$ isotopic data for these samples are shown in a histogram in Figure 2a. Included in this figure are data from $D P W$ on two MOR tholeiites and BCR-1. BCR-1 was selected as representative of the chemically and (Sr) isotopically uniform Yakima basalts of the Columbia River province, the most voluminous lava type found in that province (McDougall, 1976). The Picture Gorge sample (PG16D) was selected for analysis because it is petrochemically distinct from BCR-1. Its $\epsilon$ CHUR is much different that what appears to be the normal range for continental tholeiites, showing affinities to oceanic basalts. Sample PEA-3 was taken from an old collection and was assumed to be a Karroo basalt as it was labelled. Discussion of this sample must be deferred until it can be documented that its $\epsilon_{I}^{\text {CHUR }}$ is not a result of an incorrect age assignment. If the age is correct, this sample could be the product of massive crustal contamination or a derivative of a special mantle reservoir. As seen in the figure, the samples fall into two distinct groups. The MOR basalts have $\epsilon$ CHUR averaging $\sim+10$ and ranging from +7 to +12 while continental flood basalts have $\epsilon$ CHUR averaging $\sim 0$ and showing a range from -4 to +2 . This striking data array confirms the existence of a profound difference in ${ }^{143} \mathrm{Nd} /{ }^{144} \mathrm{Nd}$ between major basalt provinces in continental and oceanic regions. It implies the existence of two distinctly different, widespread mantle magma sources. From the difference of $f^{*} T *$ values of $\sim 4 \times 10^{8}$ yr for the two groups of samples (Table 1), and assuming a difference of $f_{s}$ of less than 0.4 , we calculate that these two reservoirs must have been separate for at least $10^{9}$ years. Thus MOR tholeiites and continental flood tholeiites appear to be derived from two ancient, profoundly different reservoirs in the earth's mantle. Differences in concentrations of certain minor and trace elements between these two lithologic types (Schilling, 1971; Haskin et al, 1966) thus are most likely a reflection of

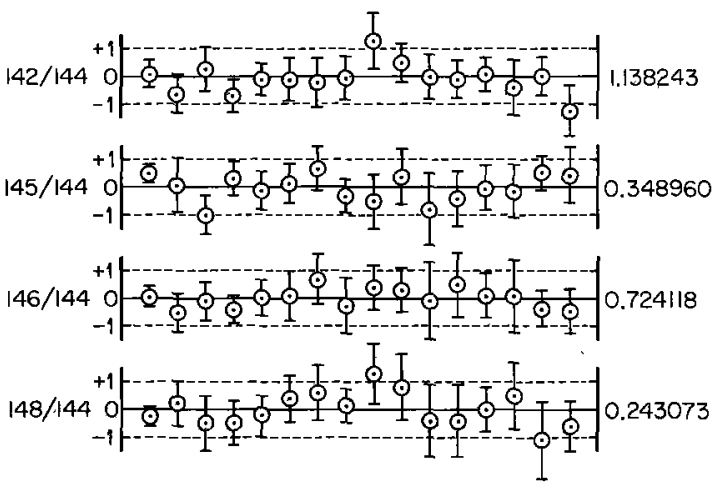

Fig. 1: Measured values of non-radiogenic Nd isotope ratios for each run plotted as fractional deviations in parts in $10^{4}$ from the average of 16 runs given at right. Ratios are normalized to ${ }^{150} \mathrm{Nd} /{ }^{142} \mathrm{Nd}=0.2096$; error bars are $2 \sigma$ mean. These data demonstrate that reproducibility of measured ratios is \pm 5 parts in $10^{5}$ or better. Measurements of non-radiogenic isotopes are used in this laboratory as an indication of data quality. 
ancient differences rather than a result of differentiation processes occurring at the time of magma generation as has been suggested (Schilling, 1971). The nominal value of $\epsilon$ CHUR $\approx 0$ for the continental flood basalts indicates they are derived from a reservoir which has maintained an unfractionated, chondritic $\mathrm{Sm} / \mathrm{Nd}$ throughout the history of the earth. The MOR basalts, however, are derived from a reservoir which has had $\mathrm{Sm} / \mathrm{Nd}$ at least $10 \%$ greater than chondritic.-

II. Other young volcanic rocks: Nd isotopic data on these samples, plus an alkali basalt from the mid-Atlantic Ridge (OAB-1) (113031 of DPW) and three ocean island samples from Richard et al. (1976) are shown in Figure 2b. With the exception of two samples, the oceanic rocks have significantly higher $\epsilon$ CHUR than the continental samples. For the most part ocean island basalts (both tholeiitic and alkalic) have $\epsilon$ CHUR of +4 to +8 , somewhat lower than those of the MOR tholeiites but definitely higher than the majority of continental basalts. The alkali basalts give no indication of being derived from an ancient light - REE enriched source, as has been suggested by Sun and Hanson (1975). Such a reservoir would yield basalts with $\epsilon$ CHUR $=-10$ to -30 . Sample OLC-1 from a $\mathrm{Na}$, Ca-carbonate lava flow represents an extreme rock type with highly fractionated REE pattern and high REE concentrations, but has $\epsilon$ CHUR identical to the average continental flood basalt. This sample thus gives no evidence that carbonatites are derived from unique mantle reservoirs. The Hawaiian tholeiite has $\epsilon$ CHUR similar to those of the continental flood basalts. A mellilite nephelinite from the same island, however, has a drastically different $\epsilon$ CHUR, similar to those found in other ocean island basalts and in MOR tholeiites. Thus these two basalts are derived from different reservoirs despite their coincident location. These data again show that a single volcanic conduit system can access a variety of mantle reservoirs of distinctive chemistry and age. The tholeiite sample provides the only evidence that the reservoir represented by the continental flood basalts is present in oceanic areas. The Pisgah crater alkali basalt (PCB) differs markedly from the other continental basalts. Its $\epsilon$ CHUR is similar to oceanic basalts and identical to that of the Picture Gorge sample. This basalt may be representative of the mantle underlying the Basin and Range province of the western United

\section{CONTINENTAL FLOOD BASALTS \\ MID-OCEAN RIDGE \\ BASALTS}

(a)
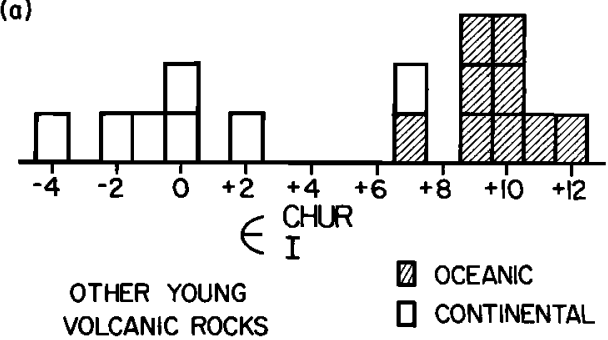

(b)

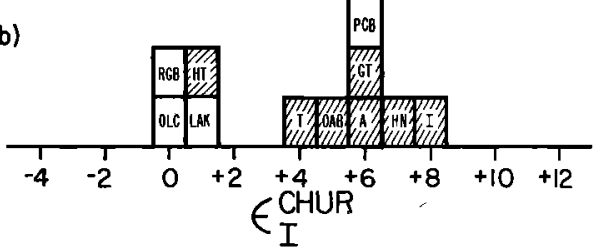

Fig. 2: Histograms of $\mathrm{Nd}$ isotopic results on young volcanic rocks and the Duluth gabbro, normalized as in $D P W$. In 2a) mid-ocean ridge samples include samples ARP74, PD1P, 111327, and AD3-3 of Richard, et. al (1976). In 2b) samples T, A, and I are samples TF110, T4, and NAL27 of Richard, et. al. (1976).

States which resembles oceanic mantle in seismic structure and heat flow. $\epsilon$ CHUR of the rhyolite sample is the same as that of the continental basalts, indicating that it appears to be derived from the same reservoir as the basalts.

III. Precambrian igneous rocks: All of the Precambrian samples analyzed, with the exception of the Mountain Pass sample, have been well-dated by other methods. The values of $\epsilon$ CHUR as a function of age for all continental samples measured in this work and by $D P W$ are shown in Figure 3. Of the samples analyzed in this work WYWR-4D and WGA210 fall within error on the CHUR evolution curve, and ZL-3D lies slightly above. The Duluth gabbro sample DUL-4, which represents an ancient continental basalt, lies slightly below the

Table 1: Nd evolutionary parameters and ${ }^{87} \mathrm{Sr}^{86} \mathrm{Sr}^{\mathrm{a}}$

\begin{tabular}{|c|c|c|c|c|c|c|}
\hline Sample & Age (AE) & $\frac{147 \mathrm{Sm}}{{ }^{144} \mathrm{Nd}}$ & $\epsilon_{0}^{\text {CHUR }}$ & $\epsilon_{\text {I }}^{\text {CHUR }}$ & $\begin{array}{c}f^{*} T^{*} \\
\left(10^{8} \mathrm{yr}\right)\end{array}$ & $\left(\frac{{ }^{87} \mathrm{Sr}}{{ }^{86} \mathrm{Sr}}\right)_{\mathrm{I}}$ \\
\hline \multicolumn{7}{|l|}{ I. Continental Flood Basalts } \\
\hline PG-16D (Picture Gorge tholeiite, Columbia R. province) & 0 & $\mathrm{~nm}$ & $+6.6 \pm 0.5$ & $+6.6 \pm 0.5$ & 2.7 & $0.70341 \pm 6$ \\
\hline DTB-8 (tholeiite, Mahableshwar plateau, Deccan, India) & 0.05 & 0.1645 & $+1.5 \pm 0.7$ & $+1.7 \pm 0.7$ & 0.7 & $0.70413 \pm 12$ \\
\hline SK-38 (tholelite, Miki's Fjord, E. Greenland) & 0.05 & 0.1329 & $-4.3 \pm 0.6$ & $-3.9 \pm 0.6$ & -1.6 & $0.70540 \pm 11$ \\
\hline SWB-1D (tholeiite, Stormberg series, Warmbad, S. Africa) & 0.15 & 0.1691 & $-1.2 \pm 0.5$ & $-0.7 \pm 0.5$ & -0.3 & $0.70630 \pm 6$ \\
\hline PEA-3 (Karroo ? basalt, Mozambique) & $0.15 ?$ & 0.1170 & $-20.1 \pm 1.6$ & $-18.6 \pm 1.6$ & -7.5 & $\mathrm{~nm}$ \\
\hline PD-1 (Palisades diabase, 200' above base, Edgewater, N.J.) & $0.20^{\mathrm{b}}$ & 0.1540 & $-1.2 \pm 0.7$ & $-0.2 \pm 0.7$ & -0.1 & $0.70604 \pm 10$ \\
\hline \multicolumn{7}{|l|}{ II. Mid-ocean Ridge tholeiites } \\
\hline VG295 (thole1ite, mid-Atlantic Ridge, 22.5N, 45W) & 0 & $\mathrm{~nm}$ & $+10.6 \pm 0.9$ & $+10.6 \pm 0.9$ & 4.3 & $0.70226 \pm 6$ \\
\hline BD37-2 (tholeiite, mid-Atlantic R.; DSDP 37-332B-19-1) & 0 & 0.1930 & $+11.0 \pm 3.0$ & $+11.0 \pm 3.0$ & 4.5 & $\mathrm{~nm}$ \\
\hline BD17-1 (tholeiite, central Pacific; DSDP 17-164-28-6) & $0.15^{\mathrm{c}}$ & 0.1988 & $+7.4 \pm 1.3$ & $+7.4 \pm 1.3$ & 3.0 & $\mathrm{~nm}$ \\
\hline \multicolumn{7}{|l|}{ III. Other young volcanic rocks } \\
\hline OLC-1 (carbonatite, Oldoinyo Lengai, Tanzanıa) & $\mathbf{0}$ & $\mathrm{nm}$ & $+0.1 \pm 0.9$ & $+0.1 \pm 0.9$ & 0.0 & $\mathrm{~nm}$ \\
\hline HN-1 (nephelinite, Oahu; USNM 113095-50) & 0 & 0.1229 & $+7.3 \pm 0.6$ & $+7.3 \pm 0.6$ & 3.0 & $0.70320 \pm 8$ \\
\hline HT-1 (tholeiite, Oahu; USNM 113095-60) & 0 & 0.1590 & $+0.8 \pm 0.6$ & $+0.8 \pm 0.6$ & 0.3 & $0.70403 \pm 6$ \\
\hline RGB-I (alk, olivine basalt, Rio Grande Rift) & 0 & $\mathrm{~nm}$ & $+0.2 \pm 0.7$ & $+0.2 \pm 0.7$ & 0.1 & $0.70436 \pm 12$ \\
\hline LAK-8D (rhyolıte, Mt. Konoctı, California) & 0 & $0.112^{\mathrm{j}}$ & $+1.3 \pm 0.8$ & $+1.3 \pm 0.8$ & 0.5 & $\mathrm{~nm}$ \\
\hline GT-2 (tholeitte, Galapagos Is., USNM 113180, F436) & 0 & 0.1155 & $+6.2 \pm 0.8$ & $+6.2 \pm 0.8$ & 2.5 & $\mathrm{~nm}$ \\
\hline PCB-1 (alk. basalt, Pisgah Crater, California) & 0 & 0.1228 & $+6.2 \pm 0.8$ & $+6.2 \pm 0.8$ & 2.5 & $0.70346 \pm 6$ \\
\hline \multicolumn{7}{|l|}{ IV. Precambrian intrusive rocks } \\
\hline ZL-3D (Town Mtn. Granite, Llano, Texas) & $1.01^{\mathrm{d}}$ & 0.1420 & $-4.4 \pm 0.7$ & $+2.3 \pm 0.8$ & 0.9 & $(0.706)^{\mathrm{d}}$ \\
\hline DUL-4 (Anorthositic gabbro, Duluth complex, Minn.) & $1.13^{\mathrm{e}}$ & 0.1036 & $-14.5 \pm 0.6$ & $-1.7 \pm 0.7$ & -0.7 & $0.70655 \pm 7$ \\
\hline MP22D (shon kinite, Mtn. Pass, California) & $1.4-1.7^{f}$ & 0.1053 & $-19.9 \pm 0.4$ & $-3-0$ & $-1.2-0$ & $\mathrm{~nm}$ \\
\hline WYWR-4D (Louls Lake granodiorite, Wind R. Mtns., Wyo.) & 2.658 & 0.1095 & $-29.6 \pm 0.6$ & $-0.9 \pm 1.0$ & -0.4 & $\mathrm{~nm}$ \\
\hline WGA2 10 (Fiskenaesset anorthosite, West Greenland) & $2.8^{\mathrm{h}}$ & 0.1146 & $-29.9 \pm 0.8$ & $-1.1 \pm 1.7$ & -0.4 & $\mathrm{~nm}$ \\
\hline
\end{tabular}

Initial ${ }^{87} \mathrm{Sr} /{ }^{86} \mathrm{Sr}$ of OAB-1 $(113031$ of $D P W)=0.70287 \pm 15 ; 111240(D P W)=0.70236 \pm 11$

a Nd data normalized as in DPW beriksen and Kulp (1961) cDSDP Inventory of Igneous Rock Recovery (1973) dZartman (1964)

eSilver and Green (1972) ${ }^{\mathrm{f}}$ Lamphere (1964) $\quad$ saylor, et. al. (1969) hancarz (1976); Black et. al. (1973) iBowman, et. al. (1973) 
curve. MP22D is not plotted due to uncertainty in its age (Lanphere, 1964). However, the age of MP22D is bracketed between 1.4 and $1.7 \mathrm{AE}$ so that its $\epsilon$ CHUR must be between -3 and 0 . Thus all of the Precambrian intrusive rocks, representing a wide variety of rock types, as well as the young continental volcanics appear to be derived from an approximately uniform, chondritic- $\mathrm{Sm} / \mathrm{Nd}$ reservoir. Note in particular that four samples with ages of 2.5 to $2.8 \mathrm{AE}$ from widely separated localities all lie within error on the curve and closely limit the position of the growth curve at $2.6 \mathrm{AE}$. Among the continental samples studied are gabbroic rocks which are taken to represent ancient continental flood basalts. All these data, when considered with the "zero" age continental samples, provide strong evidence that the CHUR curve describes Nd evolution in an important and widespread reservoir, most probably the mantle, and as such, can be taken as a representation of the bulk earth's evolution curve. As discussed by $D P W$, definition of the bulk earth evolution curve is necessary in order to infer what processes are responsible for variations of $\epsilon$ CHUR . The CHUR evolution curve given here was calculated from data of Lugmair (pers. comm.) on the Juvinas achondrite which has $\mathrm{Sm} / \mathrm{Nd}$ within $1 \%$ of the average of ordinary chondrites ( 0.309 atom ratio) as determined by Masuda et. al. (1973) and Nakamura (1974). Thus the earth appears to have $\mathrm{Sm} / \mathrm{Nd}$ and presumably $\mathrm{REE}$ relative abundances essentially identical to chondritic meteorites.

Discussion: The data shown in Figure 3 clearly suggest that the source of magmas during the first $2 \mathrm{AE}$ of Earth history was a uniform chondritic-Sm/Nd reservoir. $D P W$, however, suggested that this might only appear to be the case since the $\mathrm{Sm} / \mathrm{Nd}$ heterogeneities of $\sim 10 \%$ which can be inferred from $\mathrm{Nd}$ isotopic variations to exist today, may have produced only indiscernable isotopic differences $3 \mathrm{AE}$ ago. However, as shown by Lugmair (1975) and Lugmair, et. al. (1976), data for the moon show no suggestion of a long-lived, uniform magma source with chondritic $\mathrm{Sm} / \mathrm{Nd}$. Lunar basalts with ages of 3.3-4.0 AE show a range of $\epsilon$ CHUR from +7 to -2 which is much larger than the range shown by the terestrial samples which were formed a billion years later. The lunar data clearly indicate that planetary differentiation processes exist which could have caused sufficient $\mathrm{Sm} / \mathrm{Nd}$ fractionation to produce large variations in $\epsilon$ CHUR in old terrestrial rocks. Thus the terrestrial data suggest that the earth, unlike the moon, did not undergo an early differentiation event which greatly fractionated the rare earth elements, or if it did, a mixing process operated during the subsequent $\mathrm{AE}$ to erase the variation of $\mathrm{Sm} / \mathrm{Nd}$ produced in this event.

The data shown in Figure 3 also provide information on the origin of silicic rocks in the continental crust. As seen in Figure 3 all silicic rocks have $\epsilon$ CHUR $\sim 0$. Thus remelting of much older continental crust does not appear to be important in the formation of silicic igneous rocks. This surprising result strongly suggests that most continental igneous rocks are derived from ancient reservoirs, possibly original materials undifferentiated over all of geologic time.

The observation that the CHUR evolution curve is the locus of initial ratios of continental igneous rocks attaches age significance to the measured ${ }^{143} \mathrm{Nd} /{ }^{144} \mathrm{Nd}$ of these rocks. If the initial ${ }^{143} \mathrm{Nd} /{ }^{144} \mathrm{Nd}$ is given by the CHUR curve then measurement of $1{ }^{13} \mathrm{Nd} / 1^{144} \mathrm{Nd}$ and ${ }^{147} \mathrm{Sm} /{ }^{144} \mathrm{Nd}$ in any continental rock today gives a model age ( $\left.\mathrm{T}_{\text {CHUR }}\right)$ :

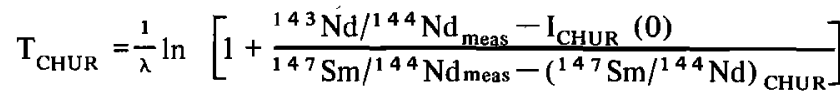

$\mathrm{T}_{\text {CHUR }}$ may provide a real "crust-formation" age for a wide variety of rocks, since studies to date have shown that metamorphism does not significantly affect REE patterns (Haskin et. al., 1968). T CHUR ages may be a way to see past metamorphic events to the time when the sialic material differentiated from its source region.

The data reported here imply the existence of at least two distinct ancient magma sources, one which supplies the MOR

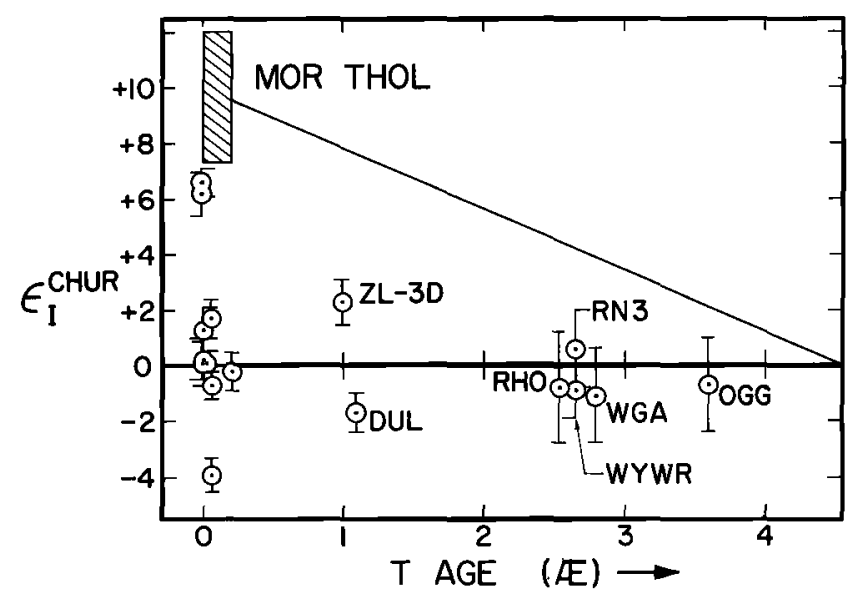

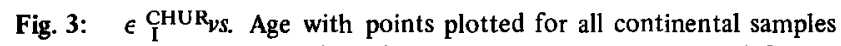
Field of mid-ocean ridge (MOR) tholeiites is shown at upper left with simple growth curve diverging from CHUR at $4.5 \mathrm{AE}$.

basalts $(\epsilon$ CHUR $\approx+10)$ and one which supplies continental rocks $(\epsilon \underset{I}{\text { CHUR }} \approx 0)$. The ocean island samples $(\epsilon$ CHUR $\approx+6)$ may either represent a third magma source, or a blend of the other two. This grouping is not a detailed description of the data as evidenced by the sizeable dispersion within each group, but is used here to assess some elementary models. For simplicity, let us assume only two sources exist, that of the continental rocks (CHUR) and that of the MOR basalts (MORR). Any model given to explain the distribution of magmas derived from these sources must take into account the constraints that 1) CHUR supplies continental igneous rocks for all time and rarely supplies magmas in oceanic areas and 2) MORR supplies oceanic igneous rocks and rarely supplies magmas in continental areas. In addition, in the process of making continental crust with low $\mathrm{Sm} / \mathrm{Nd}$, residual matter $\left(\mathrm{C}^{*}\right)$ from CHUR is left with increased $\mathrm{Sm} / \mathrm{Nd}$. This material may then evolve the Nd isotopic character of MORR after a time period of $\sim 1$ AE. Thus CHUR and MORR may be distinct entities dating from the formation of the earth (congenital sources), or MORR ( $\left.\mathrm{C}^{*}\right)$ may be derived from CHUR in the process of making continental crust (evolved sources).

One possible interpretation of the data might be that with the exception of a few anomalous areas, CHUR is found only under continents and MORR only under oceans. For stationary continents this model would be acceptable for the congenital case. For the case of evolved sources a mechanism for allowing the residual material $\mathrm{C}^{*}$ from CHUR to migrate from under the continents to under the oceans over times of $\sim 1 \mathrm{AE}$ or more is necessary. For drifting continents it is necessary that CHUR is attached to the continents. This presents a problem in that the amount of mantle present in the attached lithosphere beneath the continents is at best barely sufficient to supply the Nd now present in the continents if primitive mantle has $\mathrm{Nd}$ equal to $\sim 2 \mathrm{x}$ chondrites and continental crust has $\sim 25 \mathrm{x}$ chondrites (Taylor, 1976).

Alternatively both sources could be present under both continents and oceans. MORR (shallow) supplies the MOR basalts but is essentially inactive under continents. CHUR (deep) is active under continents and oceans, but in oceanic regions its products are volumetrically insignificant in comparison to those of MORR. This configuration is much the same as hypotheses of mantle plumes (Morgan, 1971, Wilson, 1965) and may provide a reasonable explanation of the basalt data. That is, most continental basalts and some oceanic basalts are derived from diapirs originating from CHUR deep in the mantle. This would imply that continental granitic rocks are also derived from the same deep mantle sources.

A third possibility would be that MORR exists at shallow levels only under oceans and at deeper levels under both continents and oceans. At shallow levels beneath the continents a region with the isotopic character of CHUR is maintained in a 


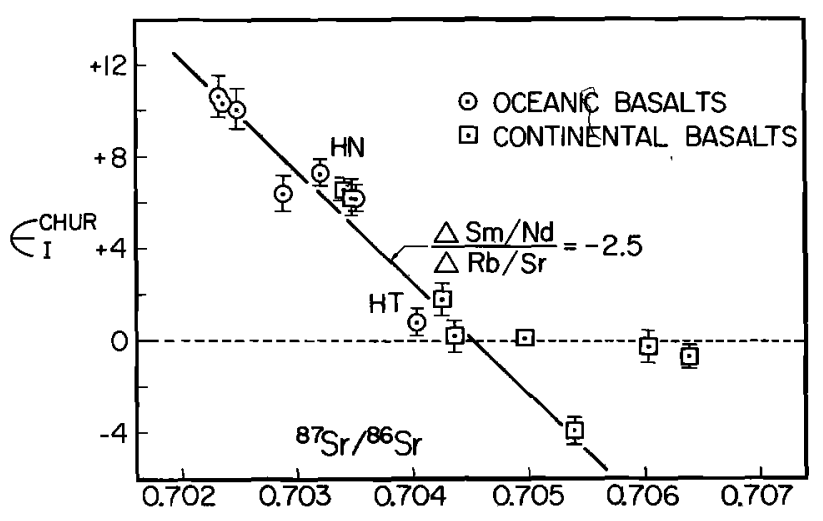

Fig. 4: $\epsilon_{1}^{\text {CHUR }} v s$. initial ${ }^{87} \mathrm{Sr} /{ }^{86} \mathrm{Sr}$ for young basalts. Included are two samples from Richard, et. al. (1976) (PD1P, ARP74) and BCR-1 $\left({ }^{87} \mathrm{Sr} /{ }^{56} \mathrm{Sr}\right.$ for BCR-1 from Pankhurst and O'Nions, 1973). The solid line shows the inferred trend of the correlation and the relative magnitudes of correlated variations of $\mathrm{Rb} / \mathrm{Sr}$ and $\mathrm{Sm} / \mathrm{Nd}$ necessary to produce such a trend. The dashed line indicates the trend defined by four continental basalt samples which have $\epsilon_{\mathrm{I}}^{\mathrm{CHUR}} \approx 0$ but different ${ }^{87} \mathrm{Sr} /{ }^{86} \mathrm{Sr}$, all lying to the right of the main correlation line. This trend may result from contamination of magmas with crustal radiogenic $\mathrm{Sr}$ or indicate the existence of magma sources which have become enriched in $\mathrm{Rb}$ relative to $\mathrm{Sr}$, but have retained unchanged $\mathrm{Sm} / \mathrm{Nd}$. Should new data populate the correlation line to values of $\epsilon_{\mathrm{I}}^{\mathrm{CHUR}}$ much less than zero, it would require serious revision of the simple two-reservoir model.

dynamic steady state. In this region $\mathrm{Nd}$ is continually transported to and stored in the crust in preference to $\mathrm{Sm}$, but is continually replenished from MORR below or by transfer in subduction zones where material from MORR passes beneath the continent. This model requires a delicate balance but is consistent with drifting continents while still implying a fundamental chemical difference between suboceanic and subcontinental mantle.

Correlation of $S r$ and $N d$. Data on samples for which both $\mathrm{Nd}$ and $\mathrm{Sr}$ isotopes were measured are shown in Figure 4 and show a correlation between initial $\mathrm{Nd}$ and $\mathrm{Sr}$. The MOR basalts have the lowest ${ }^{87} \mathrm{Sr} /{ }^{86} \mathrm{Sr}$ and highest $\epsilon$ CHUR while the continental basalts have highest ${ }^{87} \mathrm{Sr} /{ }^{86} \mathrm{Sr}$ and lowest $\epsilon$ CHUR . Oceanic alkali basalts are intermediate but can be distinguished from the continental samples. This correlation suggests that $\mathrm{Sm}-\mathrm{Nd}$ and $\mathrm{Rb}-\mathrm{Sr}$ fractionation in the formation of magma sources in the mantle are correlative. Samples PD-1 and SWB-1D may represent cases where significant $\mathrm{Sr}$ contamination occurred but the Nd isotopes were essentially unaffected. This possibility is plausible since reservoirs of extremely radiogenic $\mathrm{Sr}$ exist in the continental crust which could act as contaminants, whereas the existence of reservoirs of extreme $\mathrm{Nd}$ isotopic composition is unlikely due to the limited variation of $\mathrm{Sm} / \mathrm{Nd}$ in nature. This suggests that Nd may provide a better tool for the study of sub-continental mantle magma sources than Sr. From Figure 4 it can be seen that a value of $\epsilon$ CHUR $=0$ corresponds roughly to ${ }^{87} \mathrm{Sr} /{ }^{86} \mathrm{Sr} \sim 0.7045$. If $\epsilon{ }_{1}^{\mathrm{CHUR}}=0$ represents an unfractionated reservoir then $0.7045 \pm 5$ might be taken as the present value of ${ }^{87} \mathrm{Sr} /{ }^{86} \mathrm{Sr}$ in unfractionated mantle. From this number and BABI we calculate $\mathrm{Rb} / \mathrm{Sr}$ of unfractionated mantle material to be $0.029 \pm .003 . \mathrm{A}^{87} \mathrm{Sr} /{ }^{86} \mathrm{Sr}$ growth curve calculated from this $\mathrm{Rb} / \mathrm{Sr}$ may be more useful for interpretation of initial ${ }^{87} \mathrm{Sr} /{ }^{86} \mathrm{Sr}$ of ancient rocks than is one calculated from the present value of ${ }^{87} \mathrm{Sr} /{ }^{86} \mathrm{Sr}$ in MOR rocks $(\sim 0.7025)$.

Acknowledgements. We thank J. Gittins, T. Simkin, W. S. Baldridge, H. R. Bowman, W. G. Melson, G. Thompson, Tj. H. van Andel, V. Bowen, T. Bence, A. R. McBirney, A. J. Gancarz, L. T. Silver, and G. Goles for providing samples. This work was supported by NASA Grant NGL 05-002-188 and NSF Grant PHY 76-02724.
Variations of ${ }^{143} \mathrm{Nd} / /^{144} \mathrm{Nd}$

\section{References}

Black, L. P., S. Moorbath, R. J. Pankhurst, B. F. Windley, ${ }^{207} \mathrm{~Pb} /{ }^{206} \mathrm{~Pb}$ whole rock age of the Archaean granulite facies metamorphic event in West Greenland, Nature, 244, 50-53, 1973.

Bowman, H. R., F. Asaro and I. Perlman, On the uniformity of composition in obsidians and evidence for magmatic mixing, J. Geol., $81,312-327,1973$.

DePaolo, D. J. and G. J. Wasserburg, Nd isotopic variations and petrogenetic models, GRL, 3, 249-252, 1976.

Eriksen, G. P. and J. L. Kulp, Potassium-Argon measurements on the Palisades Sill, New Jersey, Bull. G.S.A., 72, 649-652, 1961.

Eugster, O., F. Tera, D. S. Burnett, and G. J. Wasserburg, The isotopic composition of Gadolinium and neutron capture effects in some meteorites, J. Geophys. Res., 75, 2753-2768, 1970.

Gancarz, A. J., I. Isotopic Systematics in Archean Rocks, West Greenland, unpublished Ph. D. thesis, California Inst. of Technology, 1976.

Haskin, L. A., M. A. Haskin, F. A. Frey, T. R. Wildeman, Relative and Absolute Terrestrial Abundances of the Rare Earths, in Origin and Distribution of the Elements, Ahrens, ed., Pergamon, 1178 pp, 1968.

Haskin, L. A., F. A. Frey, R. A. Schmitt, and R. H. Smith, Meteoritic, solar, and terrestrial rare-earth distributions, Physics and Chemistry of the Earth, 7, 167-321, 1966a.

Haskin, L. A., T. R. Wildeman, F. A. Frey, K. A. Collins, C. R. Keedy, and M. A. Haskin, Rare earths in sedıments. J. of Geophys. Res., 71, 6091-6105, 1966b.

Lanphere, M. A., Geochronologic studies in the eastern Mojave Desert, California, J. Geol., 72, 381-399, 1964.

Lugmarr, G. W., Sm-Nd systematics of some Apollo 17 basalts, in Origins of Mare Basalts, LSI, 205p, 1975.

Lugmair, G. W., K. Marti, J. P. Kurtz, N. B. Scheinin, History and Genesis of Lunar Troctolite 76535 or: How old is old? (in press) 1976.

Masuda, A., N. Nakamura, T. Tenaka, Fine structures of mutually normalized rare-earth patterns of chondrites, Geochim. Cosmochim. Acta., 37, 239-248, 1973.

McDougall, I., Geochemistry and origin of basalt of the Columbia River Group, Oregon and Washington, G.S.A. Bull, 87, 777.792, 1976.

Morgan, W. J., Convection piumes in the lower mantle, Nature, 230 , 42-43, 1971.

Nakamura, N., Determination of REE, Ba, Fe, Mg, $\mathrm{Na}$ and $\mathrm{K}$ in carbonaceous and ordinary chondrites, Geochim. Cosmochim. Acta., 38, 757-775, 1974.

Naylor, R. S., R. H. Steiger, and G. J. Wasserburg, U-Th-Pb and Rb-Sr systematics in $2700 \times 10^{6}$-year old plutons from the southern Wind River Range, Wyoming, Geochim. Cosmochim. Acta, 34, 1133-1159, 1970.

Pankhurst, R. J., and R. K. O'Nions, Determination of $\mathrm{Rb} / \mathrm{Sr}$ and ${ }^{87} \mathrm{Sr} /{ }^{86} \mathrm{Sr}$ ratios of some standard rocks and evaluation of X-ray fluorescence spectrometry in Rb-Sr geochemistry, Chem. Geol., 12, 127-136, 1973 .

Richard, P., N. Shimizu, and C. J. Allegre, ${ }^{143} \mathrm{Nd} /{ }^{146} \mathrm{Nd}$, a natural tracer: An application to oceanic basalts, Earth Plan. Sci. Letters, 31, 269-278, 1976.

Schilling, J. G., Sea-floor evolution: rare-earth evidence, Phil. Trans. Roy. Soc. Lond. A. 268, 663-706, 1971.

Silver, L. T. and J. C. Green, Time constants for Keweenawan igneous activity, G.S.A. Abs, 4, 665, 1972.

Sun, S. S. and G. N. Hanson, Origin of Ross Island Basanitoids and limitations upon the heterogeneity of mantle sources for alkali basalts and nephelinites, Cont. Min. Pet, 52, 77-106, 1975.

Taylor, S. R., Island arc models and the composition of the continental crust, Ewing Symposium, in press, 1976.

Wilson, J. T. Submarine fracture zones, aseismic ridges and the ICSU line: Proposed western margin of the East Pacific ridge. Nature, 207, 907-911, 1965.

Zartman, R. E. A geochronologic study of the Lone Grove Pluton from the Llano Uplift, Texas, J. Petrol, 5, 359-408, 1964.

(Received September 30, 1976; accepted November 4, 1976.) 